\title{
THEORETICAL PROBLEMS OF LEGAL REGULATION OF INNOVATIONS IN THE MEDICAL FIELD: EXPERIENCE IN COUNTERACTING COVID-19
}

PROBLEMAS TEÓRICOS DE LA REGULACIÓN LEGAL DE LAS INNOVACIONES EN EL CUIDADO DE LA SALUD: EXPERIENCIA DE CONTRARRESTAR EL COVID-19

\author{
Valentyn Fedorov ${ }^{*}$ \\ Sergii Kravchenko** \\ Hanna Reznichenko*** \\ Nataliia Opara ${ }^{* * *}$ \\ Oleg Tsybokhin
}

\begin{abstract}
The work is devoted to identifying the main problems of legal regulation of innovations in the medical field and developing the best options for solving them in the context of the Covid-19 pandemic. Thus, the research methodology is based on general and special scientific methods, in particular: formal legal, historical and legal, comparative analysis, and modeling. So, the procedure and issues to be considered are as follows. In the introduction, we will briefly highlight the origins of intellectual property
\end{abstract}

* Ph. D., Associate Professor of Department of General Theoretical Jurisprudence of National University “Odesa Law Academy” (Odesa, Ukraine). https://orcid.org/0000-00033130-2602.pom.president@gmail.com

** Director of the Center for Distance and Distance Learning, Ph.D., Associate Professor of General Theoretical Jurisprudence of National University "Odesa Law Academy" (Odesa, Ukraine). https://orcid.org/0000-0001-6252-3243. murineus@gmail.com

*** Ph. D., Odesa State University of Internal Affairs (Odesa, Ukraine). http://orcid.org/0000-0001-6386-4154. anna24@ukr.net

${ }^{* * * *} \mathrm{Ph}$. D. candidate of Department of Labor Law and Social Security Law of National University "Odesa Law Academy" (Odesa, Ukraine). https://orcid.org/0000-0003-11575013. nataliiapara@gmail.com

***** Master of Public Administration of National University "Odesa Law Academy" (Odesa, Ukraine). https://orcid.org/0000-0003-0827-9432. turistos3333@gmail.com 
rights issues in the medical field and the overall state of the pharmaceutical industry. In the first subsection of the third section, we will consider the positions of the main players in the pharmaceutical industry and the contradictions between them. In the second subsection, we will highlight the international obligations under TRIPS. In the third subsection, we will consider the consequences of their direct violation. In the fourth subsection, the impact of Covid-19 and the methods of legal regulation of medical innovations and patents under the TRIPS agreement will be discussed. In the fifth subsection, we will propose a way out and a compromise according to the Indian scenario. As a result of the study, contradictions were identified in the aspect of maintaining the balance of private and public interests between states and international pharmaceutical companies in the context of a pandemic and proposed ways to resolve them within the existing legal methods under the TRIPS agreement to achieve an acceptable compromise.

Keywords: Innovation, Coronavirus, Intellectual Property, Health, TRIPS Agreement

Resumen: El artículo está dedicado a identificar los principales problemas de regulación legal de las innovaciones en el campo médico y desarrollar las mejores opciones para solucionarlos en el contexto de la pandemia Covid-19. Esta investigación utiliza los métodos científicos generales y especiales, en particular: formal legal, histórico y legal, análisis comparativo y modelización. Se consideran las siguientes cuestiones, en el siguiente orden. En la introducción, se mencionan los orígenes de los problemas de derechos de propiedad intelectual en el campo médico y el estado general de la industria farmacéutica. En la primera subsección de la tercera sección, consideraremos las posiciones de los principales actores de la industria farmacéutica y las contradicciones entre ellos. En la segunda subsección, destacaremos las obligaciones internacionales bajo los ADPIC. En la tercera subsección, consideraremos las consecuencias de su violación directa. En la cuarta subsección, se discutirá el impacto de Covid-19 y los métodos de regulación legal de las innovaciones médicas y las patentes bajo el acuerdo ADPIC. En la quinta subsección, propondremos una salida y un compromiso de acuerdo con el escenario indio. Como resultado del estudio, se identificaron contradicciones en el aspecto de mantener el equilibrio de los intereses públicos y privados entre los estados y las empresas farmacéuticas internacionales en el contexto de una pandemia y se propusieron formas de resolverlas dentro de los métodos legales existentes en el marco del acuerdo ADPIC para lograr un compromiso aceptable. 
Palabras clave: Innovación, Coronavirus, propiedad intelectual, salud, Acuerdo sobre los ADPIC

Summary. I. Introduction. I.1. Corruption in prescribing medicines. I.2. Distributor monopoly. I.3. "Patent trolling". I.4. Trade imbalance. I.5. Authorities' reaction to the current state of pharmaceutical market. II. Analysis of recent research. III. Results and discussion. III.1. Discussion on evergreen patents. III.2. Ukraine's international obligations under TRIPS. III.3. Guarantees for the protection of foreign investments in the field of industrial property. III.4. Impact of Covid-19 and regulatory practices for medical innovation and patents. a) Appeal to emergency conditions. b) Compulsory licensing. c) Parallel import. d) Expedited generic application. e) Managed entry agreements. III.5. Proposal to resolve the evergreen patent problem: an Indian compromise. IV. Conclusions. References.

\section{INTRODUCTION}

The priority of every state is to ensure the inalienable rights and freedoms of man and citizen. Therefore, enshrining the right of everyone to health care at the international and national levels imposes appropriate responsibilities on states to ensure it.

However, the results of the USAID (2018) "(Not)expensive Medicine" study indicate that every second patient in Ukraine refuses treatment due to a lack of funds. $65 \%$ of Ukrainians surveyed resorted to borrowing money or selling the valuable property to cover the cost of medicines. And medicines purchased with payment from the patient's pocket account for $88.2 \%$. There is no other country in Europe with such low coverage of drugs by the state. Such disappointing data indicate that the right to health care in Ukraine is insufficient.

There are enough reasons for this state of affairs: the stagnation of the economy and the fall in the exchange rate of the national currency, falling incomes of the population for several years in a row, the outflow of specialists, and, as a result, the high cost of medicines and medical services. Consider the general state of affairs and what is the place of legal regulation of innovations in the medical field.

After the shock fall in 2014, the Ukrainian pharmaceutical market shows a steady growth of 5-7\% per year. The market for dietary supplements stands out as it has doubled in volume since 2017. Market growth, imperfect regulation, the fierce competition of many internal and external players have led to a number of abuses and scandals that have shaken Ukrainian society over the past few years (cf. Kirsanov, 2020). 


\section{I.1. Corruption in prescribing medicines}

It has already become a common practice for officials and company representatives to systematically provide doctors of healthcare institutions with unlawful benefits, for which doctors, using their powers, when prescribing drugs to patients, preferred the drugs of this particular group of companies.

This practice of prescribing expensive drugs from specific manufacturers and a heap of unnecessary/overlapping drugs to their patients "on the load" in prescriptions by doctors is especially aggravated during economic crises. The purchasing power of Ukrainians is falling sharply, but at the same time, the profits of pharmaceutical companies are paradoxically growing steadily. For example, this was the case during the crisis of 20082009, when, according to experts, Ukrainians overpaid for medicines up to one billion dollars, purchasing expensive medicines on the advice of doctors instead of analogs that are in no way inferior in their properties (Shcherbina, 2009).

In the same way, the Ministry of Healthcare has been taking various measures from time to time for more than a dozen years, "demonstrating" its readiness to fight these corruption schemes. Precisely by demonstrating - since corruption schemes involving pharmaceutical companies have successfully survived more than one minister of health and more than one government. In particular, the Ministry of Health has repeatedly tried to prohibit doctors from indicating the trade name of a medicine in a prescription - doctors were allowed to indicate only the active ingredient in the prescription so that the patient could already be in the pharmacy decide for himself what kind of drug with such a substance he will choose and buy. The success of this company is very moderate, given the latest high-profile cases with "promotions" - exposure of the national police to a scheme of bribery of doctors for 140 million hryvnias (Official site of the National Police, 2019).

\section{I.2. Distributor monopoly}

By 2016, three distributor companies, namely LLC "BaDM", LLC "Venta.Ltd" and LTD "Optima-Pharm" began to control $80 \%$ of the entire market for the supply of medicines to pharmacies, and their share is growing, as noted in a public report Antimonopoly Committee of Ukraine (Delo.UA, 2016). In these conditions, more and more cases of non-observance of state price discipline by pharmacy chains began to occur. According to the representative of the committee, the current system of stabilizing drug prices 
in Ukraine through state regulation of wholesale retail prices of certain drugs is, in practice, unable to ensure their affordability of drugs for the population.

As a result, in 2017, litigation has already begun, and by the decision of the Antimonopoly Committee of Ukraine dated November 14, 2017, Sanofi-Aventis Ukraine LLC (the only importer of Sanofi medicines) was fined almost 70 for anticompetitive concerted actions to multiply the prices for medicines. million UAH, as well as the largest wide assortment pharmaceutical distributors of Ukraine LLC "BaDM" of almost UAH 29 million and LLC "Optima-Pharm" for a little more than 40 million UAH (Zheltikhin, 2018). Subsequently, such violations and fines have already become regular, and the struggle between monopolists and the state continues today.

\section{I.3. "Patent trolling"}

The subject of litigation, which will be discussed below, are drugs that have been recognized as strategic today, and under the Resolution of the Cabinet of Ministers of March 20, $2020 n^{\circ} 225$ and are extremely necessary for the provision of medical care to patients with Covid-19. The list is quite extensive and can be quickly supplemented by the government. Every day, government medical institutions announce the purchase of fentanyl, diazipex, morphine, and promedol, which must be immediately delivered to medical institutions.

Raiding can take many forms, including "patent trolling". Not being an inventor or manufacturer of a product, an unscrupulous person applies for registration of a patent for an object of intellectual property rights, for example, for a utility model or industrial design, the essential features of which have long been known, so that it does not meet the criterion of novelty. The conditions for obtaining a patent are not so difficult, therefore, there are cases in Ukraine when a patent was issued for an iPad design.

Further, in addition to obtaining such an awkward patent, a person also acquires a tool to protect his "intellectual property rights" in the form of a ban on import and distribution or the right to demand the seizure of goods from a bona fide importer.

Thus, a certain enterprise "People's Health" drew attention to the products of the Latvian-Ukrainian company JSC "Kalceks", the official distributor in Ukraine of which is LLC "Diatom". And at the end of 2017, People's Health registered patents for medicines similar to those that "Kalceks" produces and supplies to Ukraine: morphine, diazepam, promedol and fentanyl. 
Next, a typical "scheme" was applied: information on the "rights" of "People's Health" for these drugs was entered into the Customs Register of intellectual property. As a result, the products of JSC "Kaltseks", which were delivered to the Ukrainian distributor "Diatom", were blocked for import at customs, although these drugs are needed by patients.

"People's Health" has already lost the dispute on the merits - the above patents were declared invalid by the Economic Court of Kyiv on July 2 , 2018. The judgment in case $n^{\circ} 910 / 4881 / 18$ entered into force on September 27, 2018.

However, the judicial interim measures were removed only during the appeal stage, the defendant incurred serious material costs, and the market was in shortage of drugs, rising prices, desperate citizens for whom these drugs are vital. The courts are still going on, since "People's Health" believes that the patents at the time of filing the claim and interim measures were valid, and the patent office just shrugs its shoulders and cannot act as a defendant. But the most worrying thing is that today dozens of cases are already underway according to a similar scenario and the judicial system is not able to quickly respond to which of the patent holders has the exclusive right, and who decided to harm competitors.

\section{I.4. Trade imbalance}

Another unpleasant feature of the domestic pharma market is a significant imbalance between products manufactured by national companies and foreign ones. Looking at Figure 1, we can observe the situation, when national companies dominate in all quantitative indicators, but foreign drugs account for the bulk of the money turnover. There are two opposing opinions to explain this situation. Representatives of foreign companies refer to the fact that Ukraine imports more complex and expensive drugs by default, plus logistics, licensing, and customs fees are imposed on this. Domestic companies, however, are called the main reason-the existence of exclusive patent rights to many formulas, modifications, and production methods of drugs that foreign companies use to get high income and prevent them from joining the game and producing cheap similar drugs.

Of course, each of the parties is pulling a blanket, but the fact remains: in 2018, products worth USD 216.2 million were exported and imported for 1947 million dollars, a difference of 9 times, and this painfully affects the trade balance of the entire country.

Thus, we have a situation where small but expensive foreign drugs collect the main profit from the market, and local manufacturers are not 
allowed to produce cheaper analogs for their fellow citizens because of patent restrictions. Naturally, this situation provokes a conflict between national interests and international obligations.

In addition to this, the pandemic has added several new challenges.

The governments of most countries have closed borders not only for people, but also for goods, even though in Europe countries and governments have actively announced the free movement of goods. As a result, it turned out that significant consignments of medicines cannot be delivered to Ukraine without the personal intervention of the top leaders of government agencies from different countries.

Another challenge that pharmaceutical companies are already facing is a significant reduction in the production of pharmaceutical raw materials and their reorientation to the domestic market-active pharmaceutical ingredients (APIs) in China. This led to a shortage and an increase in the prices of substances, and in the shortest possible time affected the prices of medicines, not only domestic but also imported ones.

Figure 1.

Market size by industry in \% between foreign and national producers-monetary value

\section{Medicines (cash) \\ Medicines (natural) \\ Cosmetics (monetary) \\ Cosmetics (natural)}

Diet supplements (monetary)

Diet Supplements (natural)

Medical products (monetary)

Medical products (natural)

Market in average (monetary)

Market in average (natural)

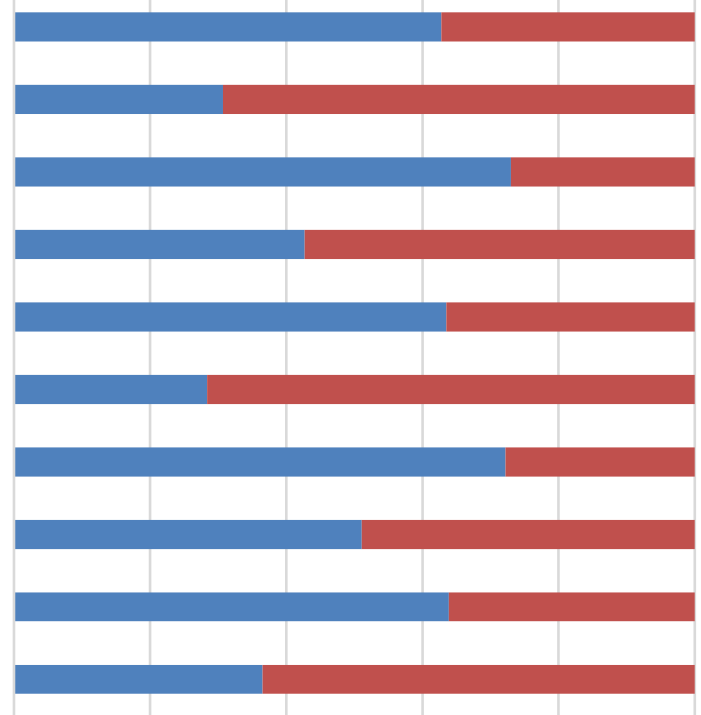

$\begin{array}{llllll}0 \% \quad 20 \% \quad 40 \% & 60 \% & 80 \% & 100 \%\end{array}$


All this testifies to the serious vulnerability of the domestic healthcare sector and the country's losing position in comparison with the leading pharmaceutical states.

\section{I.5. Authorities' reaction to the current state of pharmaceutical market}

In connection with the above problems, the government and the legislator have recently proposed many ideas and bills to restore order in the pharmacological field, but their proposals are very controversial.

So the chairman of the committee on the health of the nation, Radutsky, proposed to introduce criminal liability for overpricing of goods to fight the coronavirus and for "poor quality" advertising of drugs (RBK Ukraine, 2020). As we found out from Resolution $n^{\circ} 225$, the range of such drugs is quite wide and is regulated by the Cabinet of Ministers in manual mode. What is considered "overpriced" and "poor quality advertising" is not yet clear, but the bill is under development.

More significant and possibly key in the indicated tangle of contradictions and interests of manufacturers, society, and the state on the pharmaceutical market is the issue of evergreen patents. So back in April 2019, the Verkhovna Rada Committee on Science and Education, at the suggestion of the Prime Minister of Ukraine Groysman, recommended the Verkhovna Rada to adopt in the first reading the draft Law of Ukraine $n^{\circ}$ 9385 “On Amendments to Certain Legislative Acts of Ukraine Concerning the Implementation of Certain Provisions of European Union Legislation in the Field of Intellectual Property" (2018) (hereinafter-Draft Law $n^{\circ}$ 9385).

One of the most discussed innovations of Draft Law $n^{\circ} 9385$ is the amendment of Article 6 of the Law of Ukraine "On the Protection of Rights to Inventions and Utility Models" (1993) (hereinafter-Patent Law) to exclude so-called evergreen patents from patent protection in Ukraine.

The amendments proposed to Article 6 of the Patent Law will completely exclude patent protection for new forms, properties, or uses of medicinal products, regardless of their novelty, industrial applicability, and inventive step, are likely to violate the international obligations of the state of Ukraine in the field of patent protection under Trade-Related Aspects of Intellectual Property Rights (1994) (TRIPS) and rights and interests of global pharmaceutical companies, as foreign investors, under international agreements of Ukraine on the encouragement and mutual protection of investments.

The proposed exclusion from patent protection in Ukraine of new forms, properties, or uses of drugs is supported by the authors of Draft Law $\mathrm{n}^{\circ} 9385$ with the aim of "achieving a balance of interests between the patent 
monopoly and the right of every person to the availability of drugs." However, in light of the identified problems, interests are also involved here national pharmaceutical companies and the state in terms of trade imbalances and national security. The bill sparked a storm of discussion and debate and was eventually sent back for revision because the centers of power did not come to any agreement.

First, we will look at the positions of the various parties regarding patents and find out their contradictions.

Next, we will discuss Ukraine's international obligations in the field of patent protection, as well as the obvious inconsistency of the proposed changes with Ukraine's international obligations.

Let us consider the possible consequences of the adoption of such or ideologically close draft law for the international reputation, political consequences, and economy of Ukraine.

After that, we will study in more detail the details of the TRIPS agreement, possible compromises, and ways to circumvent existing restrictions, which is useful for both the government and pharmaceutical companies to know.

In the end, let us pay attention to India, whose experience may be useful for our country. India was the first country in the world to introduce legal restrictions on patent protection for new forms, properties, or uses of known pharmaceutical inventions in 2005 in order to counter the practice of patent abuse. Although India has been heavily criticized by the US and the EU, its approach, compared to the restrictions proposed in Ukraine, is a compromise and is generally in line with the international obligations undertaken by India.

\section{ANALYSIS OF RECENT RESEARCH}

Not many publications are devoted to the theoretical side of the problems of legal regulation of innovations in the medical field, which in one way or another are due to the emergence of the pandemic of acute respiratory disease Covid-19. However, a sufficiently developed scientific and legal framework in the field of intellectual property and medicine is currently available, which serves as a foundation for the analysis of the latest challenges in these areas.

Among the lawyers and scientists involved in the study of legal problems of innovative ways to combat the new coronavirus, we should highlight the names of Buletsa (2020), Kharytonova (2020), Zaliska and Stasiv (2019), Kashintseva (2017), Trofimenko and Ennan (2020), Gritsyk, 
Mazurenko (2020), Moskalyuk (2013), Chibisov (2017), Chepis (2020), and Senyuta (2020). Among the foreign experts who have contributed to a better understanding of this issue, the following experts can be singled out Ferrario et al. (2013, 2017), Wenzl and Chapman (2019), Silverman and Lusiani (2020), Shirsat (2011), and Heckman (2017).

Buletsa (2020) made a thorough analysis of the novelty of national legislation in the field of health care in her article. The subject of her scientific interest was controlled access agreements. Paying attention to the need to take into account all aspects related to the implementation of international practice of this type of treaty, she marks the overall positive nature of innovations and their stimulating effect in combating the spread of coronavirus infection.

In their work, civil scholars have paid great attention to the issue of intellectual property rights, which faced new challenges with the emergence and spread of the SARS CoV-2 virus. Thus, in her study, Kharytonova (2020) expressed skepticism about the general availability of Covid-19 drugs, even in the short term, recalling the practice of previous years and the nuances of patent law, which will have to be taken into account in the near future. Particular attention in this sense is paid to the current legal status of medicines used outside the instructions and for reasons of humanity. Nevertheless, the need for a fair legal settlement of this aspect from the standpoint of fundamental human rights is concluded.

A good example of the analysis of this topic is the publications of Kashintseva (2017). The jurist explores the latest challenges facing innovative jurisprudence with the spread of coronavirus infection, finds out ways to overcome the controversy caused by the pandemic in the field of intellectual property law and foreign experience in resolving them.

Ennan (2020) shares interesting considerations, in particular, in his work, he uses the historical-legal method in order to point out through the prism of international practice the conceptual obstacles to the protection of treatments, as well as the possibility of overcoming these obstacles, which is relevant for domestic legal science and medicine. In a way, his work resonates with the conclusions of Gritsyk and Stasiv (2006), who insisted on the predominance of treatment, prevention, diagnosis over pharmaceutical products in the general share of inventions of the medical field.

Considering the peculiarities of the application of the TRIPS Agreement, Mazurenko (2020) described the rules governing the circulation of patented drugs in World Trade Organization (WTO) member countries. The issues she raises in her work relate to the problematic aspects of the above-mentioned international treaty in the context of a pandemic. The models of observance of intellectual property rights, which the author 
described in her research, give an idea of the possible balance of private interests and public health.

In this context, it is also worth mentioning the name of Chibisov (2017) and his contribution to the functioning of patent law within the WTO, which served as a theoretical basis for modern scientific publications on this topic.

Furthermore, Chepis (2020) investigate the changes in the legal relationship in the field of patenting in a pandemic and the associated contradictions between public and private interests. The researcher sees their solution in the modernization of the institution of compulsory licensing, illustrating possible solutions with the latest examples of legal regulation of foreign countries.

Senyuta (2020) draws attention to the legal conflicts related to the processing of personal data related to the measures taken to counteract the spread of Covid-19. It is emphasized that legislation in this area remains flexible enough to maintain a balance between public health and individual rights, despite isolated violations of these freedoms by the media, which is unacceptable.

Finally, Moskalyuk (2013) investigated theoretical and practical problems of realization of the mechanism of parallel import of medicines in her article "Theoretical background and practical aspects of parallel imports in the system of realization of intellectual property rights to medicines". She found problems of poor legal regulation of this mechanism and illconsidered policy of public authorities in this area, and proposed some options for solving problems.

Thus, the scientific literature already raises issues of drug availability, patent relations, and issues of intellectual property in this area. But meanwhile, the issue of ensuring the balance of private and public interests, the flexibility of legal acts on patenting drugs in a pandemic remains open.

\section{RESULTS AND DISCUSSION}

\section{III.1. Discussion on evergreen patents}

The adoption of Bill No. 9385 is motivated by the need to combat evergreen patents, which are often viewed as an abuse of patent protection by the owners of patented medicines. Proponents of the proposed changes, in particular the Ministry of Health of Ukraine, national patient organizations, and pharmaceutical companies argue that global pharmaceutical companies are widely using practices that actually allow them to extend patent protection for known patented drugs. 
For example, a pharmaceutical company that owns a patent for an original drug can obtain a separate patent for one of the components of this drug before the 20-year patent period for such a drug expires, which will effectively allow the innovative company to extend the 20 -year period of protection (exclusivity) in Ukraine beyond the term of the first patent.

The proposed amendments to Article 6 of the Patent Law were supported by the Ministry of Health of Ukraine, the Scientific Research Institute of Intellectual Property of Ukraine, and the Committee of the Verkhovna Rada of Ukraine on Science and Education, where it is believed that the extension of patent protection does not always lead to an increase in the effectiveness, quality or safety of drugs, but often leads to manipulative price increases. Blocking the entry of generics into the Ukrainian market through the artificial extension of patent protection leads to the retention of high prices for medicines, which are inaccessible to the majority of the population of Ukraine (Research Institute of Intellectual Property of the National Academy of Legal Sciences of Ukraine, 2020).

According to Shymkiv (2020), a chairman of the executive board of the national company PJSC Pharmaceutical Firm Darnitsa, Ukrainian generic companies are interested in limiting the unjustified prolongation of patents for original drugs, which creates obstacles to providing patients with necessary and affordable generics.

A similar opinion is shared by the executive director of JSC "Farmak" Kostyuk: The current legislation of Ukraine in the field of protection of rights to inventions does not allow generic companies to carry out research with the aim of further registration of a generic drug until the expiration of the patent for the original drug to obtain effective generic drugs for less money. The "Bolar Regulation" (2001) allows generic companies worldwide to develop, study, research, and register generics before the patent expires on the original drug. This allows the generic to be brought to the market immediately, literally on the 2 nd day after the expiration of the patent" (Interfax Ukraine, 2018).

Draft Law n 9385 regarding the "Bolar exception" does not contain an exhaustive list of permitted actions aimed at registering a medicinal product that does not violate patent rights. Thus, the rule regulating the "Bolar exemption" does not fully comply with part 6 of Article 10 of Directive 2004/27/EU of the European Parliament and of the Council of 31 March 2004 amending Directive 2001/83/EU of 6 November 2001, contradicts the established international practice and, in general, is a step back in the harmonization of legislation with the European Union.

Pharmaceutical companies have their own legal point of view. In particular, Orlova defends the point of view that that such a rule may 
unreasonably limit the scope of protection granted to the owners of patents for medicinal products, including revoking the exclusive right to prohibit the use of a patented invention during the preparation and submission of information for the registration of other medicinal products and also create the possibility for serious abuse by unscrupulous competitors, who (referring to the preparation for registration of a generic medicinal product) will be able to import into the territory of Ukraine unlimited volumes of the active substance of a generic medicinal product and illegally distribute it during the period of validity of the patent for the original medicinal product, thereby violating the rights of the patent holder.

How do other countries deal with this conflict of interest? The approaches are completely opposite, from unconditional patent compliance in the United States, softer in Canada and Britain, to highly selective in India. In our work, we will consider in more detail the specific precedents in each country, and now we would like to dwell a little on the US approach.

The question actually boils down to how the use of patents will be regulated, because situations may occur when pharmaceutical companies will use their entire arsenal in the struggle for patents in order to obtain high profits. What is already happening on the market of auxiliary drugs (Service, 2020), which is sounding the alarm by public organizations (Silverman \& Lusiani, 2020), the media in the United States (Jorge, 2020) and is evidenced by the diverse policy of pharmaceutical companies, when some promise to produce at cost and share patents for related drugs free of charge in response to the pandemic and some are doubling prices (Kuchler, Inagaki \& Neville, 2020).

Undoubtedly, the US pharmaceutical market is the most protected for patent law, however, at the same time, it is also the most expensive drug market for consumers. Despite the high level of prosperity relative to the rest of the world, $25 \%$ of Americans have serious difficulties buying conventional drugs (Kaiser Family Foundation, 2015). One of the reasons for the companies' policy of "investing in the future" is that the prices of current drugs are overpriced by an average of 57\% compared to the EU, for "future research," as Johnson \& Johnson explicitly states (Ezekiel, 2019). The imports and licensing restrictions of the States regarding medical products from other countries add fuel to the fire, all for manufacturers, as they say. Of course, such a state of affairs, when ordinary consumers have to overpay for only possible innovations today, increases social tensions, increases property inequality, and leads to a violation of the basic rights to life and health of both Americans and residents of other countries, where a similar scheme is trying to introduce transnational pharmaceutical companies. 
And even though several companies announced sales at cost, there is a high likelihood of repeating the history of ventilators, which the US government was also forced to purchase at a five-fold overpriced (HigginsDunn, 2020). Also, the issue of priority supplies and the impossibility of increasing production capacity throughout the world remains unresolved, leading to the fact that in this situation, there will definitely be those who will receive the medicine in the first place, and who in the second.

Moreover, the pharmaceutical business is leading in terms of profitability. Thus, according to a large study by the U.S. Government Accountability Office (2017) in the United States, about $67 \%$ of all pharmaceutical companies increased the average annual profitability from 2006 to 2015. Among the 25 largest companies, the average annual profitability ranged from 15 to 20 percent. By comparison, the average annual profit margin of the world's 500 largest non-drug companies ranges from 4 to 9 percent. The level of business consolidation through acquisitions and mergers is growing, which leads to higher prices and has a negative impact on innovation, despite the multiple increase in research and development funding from the federal government.

As for the question of the cost of vaccines against Covid-19, there is a lot of speculation and populism from "shareware" at the expense of the state and charitable organizations, to the position that vaccine production will be specifically limited and distributed only among wealthy segments of the population to squeeze the maximum profit.

It is definitely difficult to say something here, however, given that the existing well-established production of influenza vaccines is at an average of about USD 40 on the market (Marsh, 2020), it is difficult to imagine that Covid-19 vaccines would cost less without subsidies from the state or charities.

The latter are actively supporting the poorer African countries, in particular, the Gavi international vaccine alliance founded by the Bill \& Melinda Gates Foundation. However, the amounts they have at their disposal cannot be compared with the budget of rich countries, so it is natural to assume that vaccination of poor countries will go on a leftover basis when the markets of rich countries are saturated and the vaccine itself becomes cheaper.

Information about cheap vaccines in the region of USD 1-10 is often flashed in the media, but the problem is that such prices are called by companies that have not actually offered anything to the market yet. On the other hand, one of the leaders in this race, Moderna, already sells for around USD 32 the first trial lots from the final tests (Lupkin, 2020). Considering the tendency for a multiple rise in the cost of childhood vaccination over the 
past 50 years (vaccination of a child in 1975, USD 10; in 2001, USD 385; in 2020, USD 1225, and this is already taking into account inflation; cf. Davis, Zimmerman, Wheeler \& Freed, 2002), there are some doubts about accessibility for the general public, at least in first time.

The issue of the quality and difference between cheap and expensive vaccines is also interesting since different technologies are used, but it is too early to talk about this because there are no voluminous statistical data.

Thus, the government of any country has several options for action: (i) pay taxpayers' money to one company (which is highly likely to be foreign) while retaining obligations in the field of intellectual law; (ii) use power and law to scale up and reduce the cost of production here and now, trampling the intellectual rights of the developer's company; and, (iii) find some compromise within the TRIPS agreement.

Of course, a commercial company aimed at profit, which incurred many risks and costs for the development of a drug, is unlikely to play charity, but for the good of the business, it would be more logical to make some compromise with many countries after receiving a guaranteed income, for example, from the sale of a license than later try to sue whose technology and who is the first.

In general, as we can see, the interests of two large blocks collided, where, on the one hand: the state, its national manufacturers, and public organizations for the protection of patients, and on the other hand, foreign pharmaceutical companies, the international TRIPS agreement, and states with the strong pharmaceutical market that is ready protect your companies abroad. Taking into account the above, we are inclined to believe that Ukraine needs to prevent the scenario of the harmful monopolization of the pharmacological market and actively engage in the development of its national manufacturers of drugs and medical devices. And most importantly, we are convinced that this can be done without violating international obligations and the interests of foreign companies. To do this, we will consider the actual current international obligations of Ukraine under the TRIPS agreement and bilateral treaties in the field of medical innovations.

\section{III.2. Ukraine's international obligations under TRIPS}

TRIPS is an international legal agreement between all member countries of the WTO. It sets out minimum standards for national governments to regulate many forms of intellectual property (IP) for citizens of other WTO member countries. TRIPS was negotiated at the end of the Uruguay Round of the General Agreement on Tariffs and Trade (GATT) between 1989 and 1990 and is administered by the WTO. 
The core of international patent protection under TRIPS is Articles 27 and 28. Article 27 of TRIPS obliges the country to grant patents to inventions, including pharmaceutical ones, which are «novel, contain an inventive step and are industrially applicable»:

Article 27. «Patentable Objects. 1. (...) patents shall be available for any inventions, whether products or processes, in all fields of technology, provided that they are new, involve an inventive step and are capable of industrial application.... patents shall be available and patent rights enjoyable without discrimination as to the place of invention, the field of technology and whether products are imported or locally produced».

Article 28 of TRIPS prohibits all third parties, including generic pharmaceutical companies, from "making, using, offering for sale, selling or importing" patented inventions, including pharmaceutical inventions.

Since all WTO member countries (today it is 164 countries) have undertaken obligations to comply with TRIPS, the norms of Articles 27 and 28 are almost universally recognized. In the event of a breach of these or other TRIPS obligations, the offending country may be held liable to other WTO member countries. WTO member countries can force an infringing country to comply with its TRIPS obligations through the WTO Dispute Settlement Mechanism, which has jurisdiction over all disputes between WTO members, including TRIPS disputes, in particular, by applying trade sanctions against the infringer.

The TRIPS patent protection system is flexible enough. Firstly, Article 27 of TRIPS does not define what should be understood by the criteria of patentability, and, therefore, WTO member countries have the right to independently interpret the "novelty", "industrial applicability", and "inventive step" of an invention. In particular, restrictive regulation (interpretation) at the level of national law or practice can significantly complicate the patenting of medicines within the national system.

Secondly, the norms of TRIPS Article 27.2 establish an exception from the general rule for granting patent protection if the "commercial use" of an invention threatens public order or morality, life or health of people:

«2. Members may exclude from patentability inventions, the prevention within their territory of the commercial exploitation of which is necessary to protect ordre public or morality, including to protect human, animal or plant life or health or to avoid serious prejudice to the environment, provided that such exclusion is not made merely because the exploitation is prohibited by their law».

Although, due to the difficulty of proving (the high threshold of the "necessity" of such health protection and the need to prove the threat to 
health precisely from "commercial use"), the possibility of the state to refuse to grant a patent for a drug due to the threat to public health regarding Article 27.2 of TRIPS looks like pretty ghostly.

Third, TRIPS allows countries to grant compulsory generic manufacturing licenses without the consent of the patent holder in emergency situations. Article 31 of TRIPS establishes the permissible conditions for compulsory licensing in the domestic market, and the Protocol amending the TRIPS Agreement from 2017 also allows export under compulsory licensing, the procedure for which is determined by Article 31 bis. The Declaration of the TRIPS Agreement and the Doha Declaration (2008) laid the foundation for the expansion of compulsory licensing practices. It was the Doha Declaration that first defined TRIPS "flexibilities" for countries with insufficient or no pharmaceutical capacity. In practice, the use of compulsory licensing, including in Ukraine, is problematic due to the government's obligation to provide adequate compensation to the patent owner.

The proposed amendments to Article 6 of the Patent Law clearly do not correspond to Ukraine's international obligations under TRIPS, since they exclude the granting of patent protection for new forms, properties, or use of already known medicines, even if they meet all the criteria of patentability under Article 27 of TRIPS.

In the event of amendments to Article 6 of the Patent Law proposed by Draft Law $n^{\circ} 9385$, Ukraine is highly likely to be included in the list of priority countries in Report 301 of the U.S. Trade Representative's Office for violation of industrial property rights. Ukraine is already on this list for copyright infringement. The addition of Ukraine to this list also for the violation of industrial property rights may lead to US trade sanctions against Ukraine and deterioration of relations with the United States. How real such consequences are, and what is the international practice in this matter, we will consider in the next section.

\section{III.3. Guarantees for the protection of foreign investments in the field of industrial property}

Bilateral treaties of Ukraine on the promotion and mutual protection of investments establish additional international obligations for Ukraine in the field of intellectual property rights protection, including the protection of industrial property.

These international treaties of Ukraine define a patent or the invention itself as a protected "investment" and provide foreign investors - owners of protected inventions or patents - with material and procedural guarantees 
for the protection of their investments in Ukraine. Tangible investment protection guarantees usually include obligations to provide fair and equitable treatment of investments, protection of investments against arbitrary or discriminatory measures, and protection against direct or indirect expropriation of investments. Moreover, international treaties usually include provisions on the application of "national treatment" and "most favored nation treatment" to foreign investments, according to which Ukraine undertakes to ensure concerning foreign investment treatment no less favorable than that which is accorded to its own investors or investors of any third the state. These regimes greatly expand the protection of foreign investment under Ukraine's numerous bilateral treaties on the promotion and mutual protection of investments.

The existing treaties of Ukraine on the encouragement and mutual protection of investments, in addition to material guarantees, provide foreign investors with procedural guarantees. In the event of a dispute on the violation of material guarantees of the rights of a foreign investor, he has the right (per the arbitration clauses, that are included in international treaties) to submit the investment dispute for consideration and decision by an independent arbitration tribunal, the decision of which is binding on the host state. The investor's right to submit an investment dispute for resolution by an arbitration tribunal is not limited by the statute of limitations and does not require the exhaustion of national remedies in the courts of the host state, which puts it in a somewhat advantageous position concerning national companies.

Investment arbitration is a very effective tool for protecting the rights of foreign investors. Let's consider it on the example of the famous case Eli Lilly v. Canada (Global Affairs Canada, 2013).

It is worth noting for a start that the Canadian courts gradually created the promised utility doctrine, thereby exploiting the legal loophole described in the first section on the possible interpretation of the utility criterion. Applying this doctrine, Canadian courts denied protection and revoked the patents of the American company Eli Lilly for the original drugs Zyprexa and Strattera, known in Canada. Such decisions by the national courts of Canada led to an investment dispute between Eli Lilly (USA) and Canada under the North American Free Trade Agreement (NAFTA).

In this case, Eli Lilly sought damages from Canada in the amount of 500 million Canadian dollars from Canada's indirect expropriation of Eli Lilly's investments, namely patents for the well-known drugs Zyprexa and Strattera. Eli Lilly's company argued that the indirect expropriation of the investment was due to a Canadian court ruling invalidating the patents, which allowed the Canadian company Novopharm (now Teva Canada) to 
obtain regulatory approvals for generic versions of these drugs. In Eli Lilly v. Canada, the arbitral tribunal ruled in favor of Canada. According to the March 3, 2017 arbitration award, the doctrine of claimed utility was evolutionarily created by the Canadian courts based on the judicious interpretation of the Canadian patent law by the courts, and the national courts' decisions based on it to revoke Eli Lilly's patents for the well-known medicines Zyprexa and Strattera cannot be regarded as unfair, arbitrary or discriminatory measures (decisions). The arbitral tribunal also ruled that these decisions of the Canadian courts did not lead to the indirect expropriation of Eli Lilly's investments in Canada.

Although Eli Lilly lost the investment dispute against Canada, the process drew strong criticism of the doctrine of declared utility from the United States. In particular, Robert Lighthizer, US Trade Representative, during a House Committee hearing on June 22, 2012, noted that the Canadian doctrine of declared utility is a significant issue that will be raised in the U.S.-Canada negotiations on the revision of the North American Free Trade Agreement (NAFTA). It is possible that precisely because of strong criticism and pressure from the United States, the Supreme Court of Canada in the 2017 decision in the case of AstraZeneca Canada v. Apotex (2017) greatly weakened the doctrine of the declared usefulness and, instead of "convincing" arguments for the claimed utility of the new invention, decided that it would be sufficient to provide at least one piece of evidence that the new invention might be useful (Heckman, 017). According to the decision of the Supreme Court of Canada:

«[Patent] Law does not define the degree or quantification of the usefulness needed, or that every possible example of utility must be proven — one aspect of utility is sufficient. One single case of utility is sufficient, and utility must be demonstrated by demonstration or reasonable anticipation [of utility] at the date of filing» (AstraZeneca Canada Inc. v. Apotex Inc., 2017).

In another case, Gilead Inc. v. Ukraine (1996), the innovation company Gilead (USA) in June 2016, notified the Government of Ukraine about an investment dispute with the state of Ukraine under the Agreement between Ukraine and the United States on the Encouragement and Reciprocal Protection of Investments. The investment dispute arose due to the illegal registration by the Ministry of Health of Ukraine of the generic version of the original drug Sofosbuvir in November 2015. Sofosbuvir is a highly effective drug that provided a revolutionary treatment for hepatitis C. Sofosbuvir was registered by Gilead in Ukraine in October 2016. Gilead promoted Sofosbuvir under the trade name Sovaldi. Generic Grateziano was registered by the Ministry of Health of Ukraine within one month after state 
registration of the original Sovaldi in violation of Gilead's legal rights to data exclusivity. Faced with the threat of an investment arbitration claiming the USD 800 million in damages, Ukraine agreed to a peaceful settlement of an investment dispute with Gilead in January 2017. Based on the World Agreement between Gilead and the state of Ukraine, the Ministry of Health of Ukraine canceled the registration of the generic Grateziano in February 2017.

Thus, we see that any significant restrictions on patent protection for pharmaceutical inventions that do not correspond to the guarantees of investment protection under international treaties of Ukraine can turn into multimillion-dollar claims for the state from foreign investors. The above investment disputes of Eli Lilly v. Canada and Gilead v. Ukraine illustrate how powerful such claims can be.

For example, the revocation by a state, its authorities, or national courts of a previously granted patent for a drug may be viewed by foreign actors as an indirect expropriation of foreign investment. Expropriation or measures that are the same as expropriation ("indirect expropriation" in TRIPS terminology) can also be considered illegal, arbitrary, or discriminatory deprivation of the patent holder for a medicinal product of protection (market exclusivity), which is granted based on a patent, for example, through state registration generic or by granting a compulsory license for generic drugs without providing fair compensation to the patent holder.

If the proposed amendments to Article 6 of the Patent Law are adopted, the Patent Office of Ukraine will have to refuse to grant patents for new forms, properties, or use of known medicines, regardless of their novelty, industrial applicability and inventive step, and national courts may revoke previously issued patents on claims from generic companies or patient organizations.

Refusal of the Patent Office to issue patents for new forms, properties, or use of known medicines, regardless of their novelty, industrial applicability, and inventive step, if applications for patents come from foreign pharmaceutical companies from states with which Ukraine has a promotion agreement and mutual protection of investments are likely to violate investment protection guarantees. For example, following the provisions of Article II.3.b) of the Treaty between Ukraine and the United States on the Encouragement and Reciprocal Protection of Investments dated March 4, 1994, Ukraine has undertaken the obligations that:

«(...) will not prevent in any way, through the adoption by [Ukraine or its authorities] of measures of an unmotivated or discriminatory nature, the management, operation, retention, use, acquisition, expansion, or disposal of investments 
[including intellectual property, including rights to inventions in all areas of human activity under Article I 1. a) IV) of the Treaty between Ukraine and the U.S.]».

The refusal of the patent office to grant a patent for new forms, properties, or use of known drugs upon the application of a company (investor) from the United States, regardless of novelty, industrial applicability, and inventive step, may be considered as an unmotivated measure that violates the rights of the U.S. investor to "acquisition" of an investment (that is, to obtain a patent in Ukraine for a new pharmaceutical invention that meets all the criteria of patentability). The investor, in this case, will have the right to present investment claims against the state of Ukraine under Article VI of the Treaty between Ukraine and the United States (which provides for an arbitration settlement of the dispute under the UNCITRAL rules or the rules of the International Center for the Resolution of Investment Disputes), and demand the termination of violation of it rights or damages.

A similar provision is contained in other treaties of Ukraine, for example, in article 2.3 of the Agreement between the Government of Ukraine and the Government of the Republic of Finland on the promotion and mutual protection of investments, signed on October 7, 2004. Although the provisions of most bilateral treaties of Ukraine that prohibit the adoption of unmotivated or discriminatory measures about investments do not apply to the "acquisition" of investments, investors from other states may have the right to demand the extension of protection against the use of unmotivated or discriminatory measures about the acquisition of investments (i.e., obtaining patents) due to the most favored nation treatment.

The decisions of the courts of Ukraine on the cancellation of previously granted patents for new forms, properties, or use of drugs, regardless of their novelty, industrial applicability, and inventive step, without adequate compensation to the owner of the canceled patent, may also violate the guarantees of protection of foreign investments from direct expropriation or measures equivalent to expropriation (indirect expropriation), as well as violate Ukraine's international obligations regarding the provision of a "fair and equitable treatment" regime for foreign investments in Ukraine, which can have very serious political and economic consequences for the country.

However, the confrontation between the main players in the field of intellectual property may also take place within the legal framework of the current agreements. In connection with the Covid-19 pandemic, it became possible to use special means and their combinations to preserve the life and health of citizens and maintain national security. Of course, direct 
expropriation is an unacceptable way of doing business and has many negative consequences, therefore, Draft Law 9385 needs to be significantly improved. We will consider in the next chapter how exactly to do this within the framework of the international legal field in modern conditions.

\section{III.4. Impact of Covid-19 and regulatory practices for medical innovation and patents}

The global epidemic of Covid-19 has especially exacerbated the problem of confrontation between the intellectual property rights of manufacturers of medical inventions and the public rights to health, which existed long before the outbreak. Specifically, we are talking about equitable access to medicines, a rather painful issue in the controversy between the WTO and the World Health Organization.

To form a legal basis for countering Covid-19, the Verkhovna Rada and the Cabinet of Ministers adopted several legislative acts providing for: (i) the abolition of Value Added Tax and duties for certain medicines, medical devices, and personal protective equipment; (ii) special tools for the acquisition of certain goods and services; (iii) significant simplification of the admission to the market of certain medical devices and personal protective equipment; and, (iv) the period of validity of registration certificates for medicinal products purchased by specialized organizations was extended, simplified procedures for state registration were introduced, and the possibility of purchasing unregistered medicinal products was established.

The Law "On Amendments to Certain Laws of Ukraine Concerning the Treatment of Coronavirus Disease (Covid-19)" (2020) amended the Fundamentals of the Legislation of Ukraine on Health Care and the Law of Ukraine "On Medicinal Products". It established that in the interests of treatment of a person with Covid-19, following the procedure approved by this Law and the protocol of the Ministry of Health, registered drugs may be used outside the instructions (off-label), as well as drugs not registered in Ukraine, recommended by the official body of the United States, the European Union, the United Kingdom, Australia, Canada and the People's Republic of China.

At present, the use of "off-label" and "compassionate use" drugs is extremely important in the war against coronavirus. As defined by the European Medicines Agency (2020), the use of the off-label medicines (outside the instructions) is "situations in which medicines are intentionally used for medical purposes not under the approved product information". Criteria for an appointment outside the instructions are the severe course of 
the disease, which threatens the life or further life of the patient, the lack of other treatment, and so on.

Compassionate use drugs (for reasons of humanity) are used when there is no alternative treatment or when the patient cannot receive it for other objective reasons. EMA states that such treatment is used outside of clinical/experimental studies.

These two types of pharmaceutical weapons are extremely relevant in the war against coronavirus, but the legal difficulties lie in how their use will be regulated, as there is reason to believe that pharmaceutical companies will use all their arsenal in the fight for patenting to make profits.

When using some drugs to counter Covid-19 "off-label" or "compassionate use", the copyright holders of such drugs may refer to the new use (area of application) of their drugs or indicate the exclusive properties of the active substance as a basis for collection with conditional defendants in such categories of cases, indicating the unfair commercial use of their intellectual property under the TRIPS Agreement as the basis for their claims, several concerns and legal difficulties arise.

The fears lie in the abuse of patent rights for the sake of profit on the part of pharmaceutical companies, both in the current legal field, using the methods described above, and in the political plane, when lobbying will create specific conditions for the functioning of the entire medical system, which we have considered on the example of the United States.

In turn, governments will look for ways to protect themselves and look for an early launch of vaccines and drugs in the wake of the Covid-19 pandemic, which seems to lead to an imminent conflict of interest.

But what is interesting, even in the current TRIPS agreement, there are arguments and opportunities to act in the legal field, which give hope that possible disputes will be resolved without high-profile court cases, without prejudice to both the national health sector and drug manufacturers. To resolve such disputes, certain mechanisms are used to balance the intellectual property rights of inventions in the medical field and public health interest. Some countries have already started using them. Let's consider them in order.

\section{a) Appeal to emergency conditions}

As already mentioned, Article 27.2 of the TRIPS Agreement establishes the right of WTO member countries to prevent the patenting of inventions, the prevention of commercial use of which is necessary to protect public order or morality, including the life and health of the population, provided that such a prohibition is not related to the restrictions 
contained in national legislation. Article 27.3.a of this Agreement provides an opportunity for signatory countries to prohibit the patenting of diagnostic, therapeutic, and surgical methods for the treatment of humans or animals. When introducing this mechanism into national legislation, it is necessary to understand that for an optimal balance between private and public interests, it is also necessary to consolidate the procedure for providing compensation. Otherwise, the rights of the owners of inventions will be significantly limited, which may lead to abuse by the state of the "emergency conditions" that are necessary to prevent the patenting of inventions.

There is also Article 73 of the TRIPS Agreement, about "security exceptions", which in $\S b 3$ defines the broad powers of the state regarding the ability to use patents in time of war or emergency in international relations. Are pandemic, border closures, and increased trade competition considered extraordinary circumstances?

An example of such a limitation is the amendments to the German Patent Law. Such changes were proposed in connection with the announcement of the Covid-19 pandemic and provided for the state's ability to impose restrictions on the validity of patents for medicines in the event that the state recognized the presence of a so-called «epidemiological situation of national importance» (Musmann, 2020).

And, while a patent holder who has been restricted in this way is entitled to fair compensation, there is serious uncertainty about the final amount and timing. This method is very tempting for states that want to solve problems here and now, and most likely the next government will deal with compensation. So, for pharmaceutical companies, the use of this method is undesirable and it is always better to agree with the state on specific figures "here and now" than to sue for a long time and possibly fruitlessly on compensation from positions that are not favorable for themselves since appeals to emergency conditions are both morally justified and legally acceptable under current legislation.

\section{b) Compulsory licensing}

Another mechanism, that will allow balancing private and public interests in such cases, is the compulsory licensing of inventions, the object of which is the concept of "medicine", to protect public health. Such a mechanism is provided for in Article 31 of the TRIPS Agreement, which guides the WTO member countries in establishing the rules for issuing compulsory licenses. However, it cannot be said that the institution of compulsory licensing owes its origin to the influence of the coronavirus. The legal definition of a compulsory license was approved as early as the text of 
the Paris Convention for the Protection of Industrial Property since 1883. The essence of compulsory licensing is that in exceptional cases it may be permitted by law to grant a license without the consent of the patent owner.

Following the TRIPS agreement, compulsory licensing is allowed only if the state observes special conditions: (i) the permission for such use must be issued only after a case has been considered on the merits; (ii) the license can be issued in exceptional cases and only if the applicant has already tried to obtain it on reasonable commercial terms (such a requirement may be delayed in the event of a national emergency or other circumstances of extreme necessity, or cases of public non-commercial use); (iii) the scope and duration of such a license should be limited; it should not give the applicant exclusive rights; (iv) the main purpose of its issuance should be to ensure the internal market of the member, allowed such use; and, (v) its effect may be terminated if the circumstances based on which it was issued have disappeared, but subject to the legal rights of the party to whom the license was granted.

The international application experience is very different. In India, in March 2012, to combat kidney and liver cancer, the Indian Patent Office officially allowed the Indian company Natco Pharma to produce and sell an analog of Nexavar at a price of $3 \%$ of the price of the original with $6 \%$ royalties from Bayer. The difference from the initial price of the drug, set by the patent owner, Bayer, was 97\%. In March 2013, Bayer lost a dispute with Natco Pharma and appealed to the Mumbai Supreme Court. The decision on compulsory licensing was revoked only after another Indian company Cipla reduced its analog prices by $75 \%$ (Kirichenko, (2020).

In turn, Israel used this method at the very beginning of the pandemic as a lever of pressure on AbbVie with the drug "Kaletra". If the company does not allow the state to purchase generics of the drug abroad at prices lower than the original prices, then local national manufacturers will receive a carte blanche for the production of Kaletra under the compulsory licensing mechanism. As a result, AbbVie had to agree and authorize the purchase of generics, probably to avoid a dangerous precedent for itself, which could be repeated in other countries. Recall that Kaletra is used to treat HIV/AIDS and is also used to treat coronavirus in the CIS countries (Silverman, 2020).

In Ukraine, the issue of compulsory licensing is regulated by the Law of Ukraine "On the Protection of Rights to Industrial Designs" (Article 30), the Resolution of the Cabinet of Ministers of Ukraine "On Approval of the Procedure for Granting Permission by the Cabinet of Ministers of Ukraine to Use a Patented Invention (Utility Model) Concerning Medicines" (2004) and the Law of Ukraine "On the Protection of Rights to Inventions and Utility Models" (1993). 
Many scholars, however, express opinions about the danger of using such a mechanism in the Ukrainian legal field, due to the lack of domestic precedents for its application. Among the justified risks is the massive nihilism of patent rights and abuse of such a mechanism, as described above in "patent trolling". The fact is that the Law of Ukraine "On the Protection of Rights to Inventions and Utility Models" provides for the presence of several conditions that are necessary for the application of "compulsory licensing" for inventions or utility models that are still under patent protection. Among such conditions, in particular, is the unjustified refusal of the patent holder to issue a license to use the invention. Proceeding from the fact that now in Ukraine, there are no judicial precedents for such cases, and the relevant state bodies have provided an explanation, the importance of individual grounds for refusing to issue a license remains an evaluative concept. Among other problematic issues, attention is also noted on the terms for which such permits must be provided, and, in addition, the granting of the legal status of a participant in this procedure to the patent holder. This mechanism, in the presence of detailed legal regulation, can become a good option for solving the existing problems of ensuring a balance of private and public interests.

Besides, the issue of the proportionality of compensation to patent holders remains unresolved. There are no criteria under the TRIPS Agreement that would help solve this problem. To make it easier for governments and courts to calculate the level of remuneration, World Health Organization and the United Nations Development Program (UNDP) have developed a special document-Remuneration Guidelines for NonVoluntary Use of a Patent on Medical Technologies (2005). It may be advisable for government or judicial authorities to develop a specific clarification based on this setting.

\section{c) Parallel import}

The TRIPS agreement also allows the so-called parallel import, which means the purchase of a drug that is lawfully placed by the patent owner on the market of another WTO member, at a lower price. The Article 51 of the Agreement, in particular, states that there should be no obligation to apply customs clearance procedures to imports of goods released on the market in another country by the owner of the intellectual property right or with his consent, or to transit goods. However, there is a ban on parallel imports of medicines by members of the European Union from non-EU countries and the European Free Trade Association (Kyrychenko, 2020). 
In Ukrainian legal circles, the question has long been whether Ukraine belongs to the countries where parallel imports are allowed or not. The adoption of the Law of Ukraine $n^{\circ}$ 202-IX of October 17, 2019 (which amended item 1 part 3 of Article 397 of the Customs Code (2012)) put an end to this issue. According to this Law measures to promote the protection of intellectual property rights (procedures to stop customs clearance by customs authorities of imported goods) do not apply to original goods, i.e., goods that were manufactured with the consent of the right holder, or goods made by a person duly authorized by the right holder to produce a certain number of goods, including in excess of that agreed between that person and the right holder. These differences resonate favorably with European law in this area, namely with the preamble to Regulation (EU) $n^{\circ} 608 / 2013$ of 12 June 2013 (Agencia Tributaria, n.d.). However, the parallel import of medicines registered in Ukraine is still impossible, as key changes on this issue need to be made in the Law on Medicinal Products.

Kuzmenko (2016) in the work "Parallel imports-an important mechanism for the existence of competitive relations" points to the main advantages and disadvantages of the introduction of such a mechanism for drugs. Among the positive aspects, of course, is the reduction in product prices, and the need for rights holders to monitor the quality of goods more closely. However, the last positive point is associated with negative consequences for the right holder, if his efforts to ensure the quality of the product will not be adequate returns to the market. In addition, the introduction of such a mechanism may result in an increase in the flow of counterfeit drugs. Thus, despite all the advantages of the introduction of the mechanism of parallel import of medicines in Ukraine, it is necessary to prescribe in detail and clearly the procedure from the very beginning of procurement for further import, until the moment of admission to the market. In particular, as the researcher suggests, the solution to the problem of the emergence of a significant number of counterfeit products is the creation of special customs posts for parallel importers. If all the above nuances are taken into account, the introduction of such a mechanism will be an extremely positive practice.

\section{d) Expedited generic application}

There is another relevant mechanism-accelerated filing by manufacturers of applications for registration of generic versions of patented drugs. Manufacturers of generic drugs can apply for registration of an analog of the drug, which is still protected by a patent. After the expiration of the patent, the manufacturer may immediately begin production of the drug, if 
its registration has already been completed. This will reduce the time required to enter the market for generic drugs after the expiration of the patent and, consequently, increase competition.

Let us consider this mechanism in the context of European practice. Thus, obtaining a permit for the production of medicines in the European Union countries and regulating their circulation is carried out by Directive 2001/83/EC and Regulation $n^{\circ}$ 726/2004/EC.

To perform accounting and flow management, a consolidated database operates based on Directives 2001/83/EC and 2001/82/EC - EudraGMDP. The database contains the following information: license for production, wholesale supply, import; certificate of compliance with the requirements of Good Manufacturing Practice (GMP), Good Distribution Certificates (GDP); applications for non-compliance with GMP, GDP requirements, plans to inspect industrial sites of third countries for compliance with GMP requirements; registration of manufacturers, importers and distributors of active substances for human use located within the European Economic Area.

When applying for permission to manufacture a generic drug, the applicant must provide information that the drug is an analog of the original (reference) drug. In particular, it is indicated: name of the drug, concentration, dosage form, holder of the marketing authorization, first authorization to manufacture, jurisdiction (EU member state/regulator). Besides, applicants provide information on the patent status of the reference product or existing agreements with the copyright holder.

If it is necessary to use an expedited application for a generic remedy, a multilateral commission is convened, which includes: a representative of the applicant company, a representative of the patent holder's company and authorized representatives of the European Medicines Agency and, if necessary, representatives of the national health department, from the country concerned. Together they define the reasons for the expedited application (for example, the lack of a reference drug in the market) and the course of action to ensure the best interests of all parties. The decision is enshrined in a multilateral agreement between all participants and violation of its execution can be freely appealed in court.

\section{e) Managed entry agreements}

Managed entry agreements have also become very important in the fight against coronavirus. The object of such contracts are medicines, and the mandatory conditions are the volume of procurement, the term of the contract, the circumstances, and the procedure for its termination. Other conditions may also be provided that do not conflict with the international 
or national law of the parties, moral standards, or established business practice. The parties in the managed entry agreements are the supplier (pharmaceutical company) and the customer (state). Authorized persons from both parties are also allowed to participate (Zaliska \& Stasiv, 2019).

The fact is that when concluding these contracts, having received certain guarantees from government agencies (for example, regarding the volume of purchases), and the manufacturer sells them such drugs at a cheaper price, which is not disclosed to the public. After such a purchase, the state can either sell such drugs at a much cheaper price or provide them free of charge. The duration of such contracts is usually from 1 to 5 years, depending on the terms of procurement and may be terminated early.

The legislation of European countries treats the issue of confidentiality of the content of such agreements differently. For example, in the United Kingdom, Italy and Sweden, there are registers of managed entry agreements with open information about medicines for which such agreements have been concluded, while in France and Belgium their content is confidential to all participants (Ferrario et al., 2017).

The introduction of the mechanism of controlled access agreements in Article 79-1 of the Fundamentals of Ukrainian Legislation on Health Care (1993) is certainly a positive step towards increasing the availability of medicines for the population; however, the conclusion of such agreements requires the allocation of significant funds from state or local budgets, which is not always possible. Besides, the confidential component of such agreements may be grounds for corruption, which is why some countries are implementing the above-mentioned measures to eliminate it.

The practice also confirms that in resolving disputes, the courts will be guided by the approval of the balance of health interests and intellectual property rights. For example, in its conclusions from 22 January 2020, the European Court of Justice sided with the transparency and openness of these experiments on the effectiveness of drugs against Covid-19 (Curia Europa, 2020).

The European Court of Justice in these cases approves the maximum availability of medical test achievements. As an exception, it is stated that such information cannot be used in general if it would harm the commercial interests of others by disclosing data that was not available, which in itself is excluded, as such clinical trials use already known and available information, does not enter under the protection of trade secrets.

An interesting precedent was the case in Brescia, Italy. In the midst of the coronavirus epidemic, the local hospital ran out of ventilators. After failing to reach an agreement with the manufacturer, doctors and activists found businessman and engineer Christian Fracassi, who agreed to make 
them for free on his 3D printer (Sparaciari, 2020). As a result, the right holder promised to go to court. However, the right to prohibit does not apply to acts committed for personal or non-commercial purposes (Article 41 of the Italian Code of Industrial Property (2005)). And in this case, we are talking about clearly non-commercial use (Tomarov, 2020).

Here is another example from another time, which, however, clearly illustrates the essence of non-profit as an important feature in resolving patent disputes. Elsewhere under British jurisdiction, exceptions to the general rule of restricting the patentability of treatments were made until 1914, but the case In the Matter of C \& W's Application for a Patent became a textbook example for all such cases in the future. In this dispute, the Attorney General insisted on the lack of grounds for issuing documentation confirming the right to protection of the method of extraction of toxic lead from the human body, as he believed that this method could not be used in any commercial or industrial sector, especially in hostilities, from which it is concluded that the commercialization of such a process would be contrary to the humane goals of the Institute of Medicine.

A review of existing mechanisms showed that, upon a more detailed examination, in a pandemic, the TRIPS agreement provides quite broad opportunities for interaction between international pharmaceutical companies, government, and national manufacturers. Moreover, companies that do not cooperate on one of the proposed options are likely to run the risk of being left with nothing, because emergency times give governments much more legal and moral power to ease patent pressures. Therefore, the strategy of cooperation with governments and their state orders is seen as mutually beneficial for manufacturers.

\section{III.5. Proposal to resolve the evergreen patent problem: an Indian compromise}

However, the problem of green patents in Ukraine exists regardless of the pandemic. To resolve it in a way that will not violate international obligations under TRIPS and treaties on the encouragement and mutual protection of investments, Ukraine should seriously study the experience of India. The patent law of that country is considered to be within the international patent protection system.

Like Law $n^{\circ}$ 9385, Section 3 (d) of the Indian Patent Act (1970) restricts legal protection for new forms, properties, or uses of previously known substances. However, instead of the absolute exclusion of all such objects (salts, ethers, polymorphs, other derivatives), Indian law excludes 
from patent protection only those drugs that do not lead to a significant increase in the effectiveness of an already known substance:

«3. What is not an invention in the understanding of this Act

d) the mere discovery of a new form of a known substance which does not result in the enhancement of the known efficacy of that substance or the mere discovery of any new property or new use for a known substance or of the mere use of a known process, machine or apparatus unless such known process results in a new product or employs at least one new reactant.

Explanation. - For the purposes of this clause, salts, esters, ethers, polymorphs, metabolites, pure form, particle size, isomers, mixtures of isomers, complexes, combinations and other derivatives of known substance shall be considered to be the same substance, unless they differ significantly in properties with regard to efficacy».

The Indian Patent Act introduced the world's first significant "efficiency gain" standard to distinguish between pharmaceutical derivatives that meet the conditions of patentability and those that do not result in significant efficiency gains and are not subject to patent protection.

This approach became known after the Novartis case, when India refused to grant a patent for a new form of the active substance of the famous drug Glivec (which was previously patented by Novartis for the treatment of leukemia), concerning the fact that increasing the bioavailability of the drug is not enough to state a significant "increase in the effectiveness" of this the drug. In a Novartis appeal against the Indian Patent Act, the Indian Supreme Court ruled that the requirement for significant "efficiency gains" for patent protection purposes in India was in line with the Indian Constitution and India's international TRIPS obligations under the TRIPS "flexibilities" (PharmaTimes, 2013).

Also, the legislation of India in the field of intellectual law suggests that companies that seek to produce a generic drug can apply for a copy of the original drug after three years from the date of the latter on the market, subject to the payment of royalties to the original manufacturer, which of course narrows the gap between national and foreign manufacturers (Joshi Attorneys, 2020).

As further researches showed, the result was the production of the same drug by several companies at the same time while changing the production process as it suits them. All of these reforms have led to lower prices for drugs, increased accessibility to the population, and the rapid growth of the Indian pharmaceutical industry (Shirsat, 2011).

The Novartis case drew global attention to the extent to which this patent limitation could be considered compatible with TRIPS. According to one of the most common approaches, the standard of significant "efficiency 
gains" is an interpretation of the criteria of "industrial applicability" and "inventive step", which (the interpretation) does not contradict the patentability requirements defined in Article 27 of TRIPS.

Since the significant "efficiency gains" standard is considered to be compatible with TRIPS, its implementation in the Indian Patent Act should not be viewed as arbitrary or unreasonable, which violates the material guarantees of protection of foreign investors' rights under India's investment promotion and mutual protection treaties. We believe this experience should be implemented in Ukraine.

\section{CONCLUSIONS}

As a result of the study of this topic, several problematic issues related to the legal regulation of innovations in the medical field, which existed in patent law before the outbreak of Covid-19, and have been developed since the announcement of the pandemic have been studied.

1. The state of the pharmacological market in Ukraine is rather sad and threatens to worsen due to the pandemic. Corruption in prescribing medicines, monopolization of distribution and pharmacy networks, "patent trolling", trade imbalance, and unrealized potential of domestic manufacturers due to patent restrictions that last for decades. As a consequence, the government proposes Bill 9385, which, however, will create many other problems.

2. The main problem in the context of the research subject is the conflict of interests of Ukrainian producers, consumers, and Ukraine in general, on the one hand, and large pharmaceutical companies, and international law, on the other. Each of the parties has its own interests, however, the review of the arguments and foreign experience inclines us to the conclusion that Ukraine needs to prevent the scenario of a harmful monopolization of the pharmacological market and to actively engage in the development of its national manufacturers of medicines and medical devices, especially in a pandemic, when the life and health of many people depend on it.

3. However, we consider the path chosen by our government to be somewhat short-sighted. The proposed amendments to Article 6 of the Patent Law, according to Draft Law 9835, clearly do not correspond to Ukraine's international obligations under TRIPS, and if adopted or similar in ideas, Ukraine is highly likely to fall under the sanctions of the US government, which will protect the interests of its companies abroad. Such potential consequences would be extremely negative for the rest of the 
country's economy. We examined the reality of sanctions, multimilliondollar lawsuits, and lengthy litigation using examples of precedents in Canada and the UK.

4. The global epidemic of Covid-19 not only exacerbated the problem of intellectual property rights of manufacturers of medical innovations but also provided an opportunity for their settlement within the framework of existing international legislation - namely, the TRIPS agreement.

These include: (i) response to the refusal to provide public access; (ii) appeal to emergency conditions; (iii) compulsory licensing; (iv) parallel import; (v) expedited generic application; and, (vi) managed access contracts.

A review of these mechanisms showed that, upon a more detailed examination, in a pandemic, the TRIPS agreement provides quite broad opportunities for interaction between international pharmaceutical companies, government, and national manufacturers. Moreover, companies that do not cooperate on one of the proposed options are likely to run the risk of being left with nothing, because emergency times give governments much more legal and moral power to ease patent pressures. Therefore, the strategy of cooperation with governments and their state orders is seen as mutually beneficial for manufacturers.

5. To resolve the problem of evergreen patents in Ukraine in a way that would not contradict Ukraine's international obligations under TRIPS and its bilateral treaties on the encouragement and mutual protection of investments, Ukraine should pay attention to the experience of India. Indian law (Article 3 (d) of the Indian Patent Act) is considered an example of a compromise - on the one hand, protecting the rights and interests of innovative companies that invest resources in researching new forms, properties or uses of already known drugs, if they lead to "significant efficiency gains", and, on the other hand, protecting the interests of generic companies and patients from abuse through unreasonable prolongation of patent protection. 


\section{REFERENCES}

Agencia Tributaria. (n.d.). Analysis of the EU Regulation n ${ }^{\circ}$ 608/2013 of 12 June 2013 on customs enforcement of intellectual property rights, which repeals Council Regulation (EU) $n^{\circ} 1383 / 2003$. Analysis of the implementation Regulation of the European Commission $\mathrm{n}^{\circ} 1352 / 2013$. In https://ukrpatent.org/i_upload/file/02-Training-of-customs-officials-Regulation052016.pdf.

Buletsa, S. B. (2020). Features of the contract of controlled access in the conditions of Covid-19. In http://dspace.onua.edu.ua/handle/11300/12616.

Canada. Supreme Court. (2017). AstraZeneca Canada Inc. v. Apotex Inc.: Judgment. In https://scc-csc.lexum.com/scc-csc/scc-csc/en/item/16713/index.do.

Chepis, O. I. (2020). Ensuring the balance of interests of right holders and society in the application of compulsory licensing in the conditions of Covid-19. In http://dspace.onua.edu.ua/handle/11300/12616.

Chibisov, D. M. (2017). Protection of intellectual property rights within the World Trade Organization. Odesa: Phoenix. In http://hdl.handle.net/11300/7382.

Chirikhin, S. N. (2009). Is the rise in drug prices again the fault of the monopolies? AllRussian economic journal ECO, 1, 36-50. https://cyberleninka.ru/article/n/vzlet-tsen-na-lekarstva-opyat-vinamonopoliy/viewer.

Curia Europa (2020). PTC Therapeutics International v. EMA; MSD Animal Health Innovation and Intervet International v. EMA. In http://curia.europa.eu/juris/document/document_print.jsf?docid=222504\&text= $\&$ dir $=\&$ doclang $=E N \&$ part=1\&occ $=$ first $\&$ mode=lst $\&$ pageIndex $=0 \&$ cid $=1853575$.

Davis, M. M., Zimmerman, J. L., Wheeler, J. R. C. \& Freed, F. L. (2002). Childhood Vaccine Purchase Costs in the Public Sector: Past Trends, Future Expectations. American Journal of Public Health, 92(12), 1982-1987. In https://www.immunize.ca/sites/default/files/resources/702e.pdf.

Delo.UA. (2016). Pharmacy chains create a monopoly, and $80 \%$ of drug supplies to Ukraine are controlled by 3 distributors. In https://delo.ua/business/aptechnyeseti-sozdajut-monopoliju-a-80-postavok-lekarstv-v-ukra-325399/.

Ennan, R.E. (2020). Methods of treatment as objects of patent law: world experience.

Problems of legal regulation of civil relations in terms of Covid-19, 1, 41-45. In http://dspace.onua.edu.ua/handle/11300/12616.

European Commission (2001). Directive 2001/83/EC. In https://ec.europa.eu/health/sites/health/files/files/eudralex/vol1/dir_2001_83_consol_2012/dir_2001_83_cons_2012_en.pdf.

European Parliament (2004). Regulation (EC) n 726/2004. In https://eurlex.europa.eu/legal-content/EN/TXT/?uri=celex\%3A32004R0726.

Ezekiel, L. E. (2019). Big Pharma's Go-To Defense of Soaring Drug Prices Doesn't Add Up. The Atlantic. In https://www.theatlantic.com/health/archive/2019/03/drug- 
prices-high-cost-research-and-

development/585253/\#: :text=Many\%20drugs\%20cost\%20more\%20than,whic h\%20there\%20are\%20definitive\%20data.

Ferrario, A. \& Kanavos, P. (2013). Managed entry agreements for pharmaceuticals: the European experience. Brussels: EMiNet. 2013. In http://eprints.1se.ac.uk/50513/.

Ferrario, A., Araja, D., Bochenek, T., Catic, T., Danko, D., Dimitrova, M., Furst, J., Greiciute-Kuprijanov, I., Hoxha, I., Jakupi, A., Laidmae11, E., Loblova, O.,' Mardare, I., Markovic-Pekovic, V., Meshkov, D., Novakovic, T., Petrova, G., Pomorski, M., Tomek, D., Voncina, L., Haycox, A., Kanavos, P., Bonanno, P.V., Godman, B. (2017). The Implementation of Managed Entry Agreements in Central and Eastern Europe: Findings and Implications.

PharmacoEconomics, 35(1). DOI 10.1007/s40273-017-0559-4.

Finland \& Ukraine. (2004). Treaty between the Government of Ukraine and the Government of the Republic of Finland on the promotion and mutual protection of investments. In http://search.ligazakon.ua/1_doc2.nsf/link1/MU04261.html.

Gilead Sciences Inc. v. Ukraine. (1996). In https://arbitration.org/award/688.

Global Affairs Canada. (2013). Eli Lilly and Company v. Government of Canada. In https://www.international.gc.ca/trade-agreements-accords-commerciaux/topicsdomaines/disp-diff/eli.aspx?lang=eng.

Gritsyk, A. R. \& Stasiv, T. G. (2006). The method is the main object of patent law in the pharmaceutical industry. Problems of modern medical science, 1, 45-48.

Heckman, A. (2017). Supreme Court of Canada Rejects the Promise of the Patent Doctrine. Gowling WLG. In https://gowlingwlg.com/en/insightsresources/articles/2017/promise-of-the-patent-doctrine/.

Higgins-Dunn, N. (2020). House report accuses Trump administration of 'waste, fraud or abuse' in U.S. ventilator contract. $C N B C$. In https://www.cnbc.com/2020/07/31/coronavirus-house-report-accuses-trumpadministration-of-waste-fraud-or-abuse-in-us-ventilator-contract.html.

In the Matter of C \& W's Application for a Patent. Reports of Patent. (1914). Design and Trade Mark Cases, Volume 31(9), 235-236. DOI 10.1093/rpc/31.9.235.

India. (1970). Patent Act. In http://ipindia.nic.in/writereaddata/Portal/ev/sections/ps3.html.

Interfax Ukraine. (2018). PJSC "Farmak" supported the resolution to support the draft law $n^{\circ}$ 9385. In https://interfax.com.ua/news/press-release/555670.html.

Interfax Ukraine. (2020). Top 10 largest pharmacy chains will consolidate up to $70 \%$ of the market over the next few years-forecast. In https://interfax.com.ua/news/pharmacy/666614.html.

Interfax-Ukraine. (2020). Compulsory licensing of drugs to combat coronavirus can be a "Pandora's box" for the pharmaceutical market-a lawyer. In https://ua.interfax.com.ua/news/pharmacy/651558.html.

Jorge, M. (2020). Opinion: Big pharma is taking big money from U.S. taxpayers to find a coronavirus vaccine - and charge whatever they want for it. Market Watch. In 
https://www.marketwatch.com/story/big-pharma-is-taking-big-money-from-ustaxpayers-to-find-a-coronavirus-vaccine-and-charge-whatever-they-want-for-it2020-06-24.

Joshi Attorneys. (2020). Changes in India's Patent Law. In https://www.joshiattorneys.com/Cross-Border-And-International-LawTopics/In-the-

Shadows.shtml\#: :text=However\%2C\%20since\%201970\%2C\%20India\%20ha s,molecule $\%$ 20yields\% 20a\% 20new\% 20patent.

Kaiser Family Foundation (2015). Most Say They Can Afford Their Prescription Drugs, But One in Four Say Paying is Difficult, Including More Than Four in Ten People Who are Sick. In https://www.kff.org/health-costs/press-release/mostsay-they-can-afford-their-prescription-drugs-but-one-in-four-say-paying-isdifficult-and-more-than-four-in-ten-for-people-who-are-sick/.

Kashintseva, O. Y. (2017). Compulsory licensing of medicines: EU experience. Theory and practice of intellectual property, 3, 38-42. In http://www.inprojournal.org/wp-content/uploads/2017/10/KashyntsevaO._317.pdf

Kharytonova, O. I. (2020). On the use of off-label drugs (out of instructions) and compassionate use (for reasons of humanity), Covid-19, and new opportunities and challenges in the context of intellectual property protection. In http://dspace.onua.edu.ua/handle/11300/12616.

Kirichenko, I. A. (2020). Forced import substitution, or where does TRIPS + lead? Lexology. In https://www.lexology.com/library/detail.aspx?g=fb95962d-a6d54b0a-b36f-63ae203c9f91.

Kirsanov, D. (2020). Pharmacy market of Ukraine. Helicopter View. In https://www.apteka.ua/article/531429.

Kuchler, H., Inagaki, K. \& Neville, S. (2020). The global hunt for a coronavirus drug. Financial Times. In https://www.ft.com/content/91bd081e-6e7b-11ea-9bcabf503995cd6f.

Kuzmenko, L.G. (2016). Parallel imports_-an important mechanism for the existence of competitive relations. Scientific notes of NaUKMA. Economic Sciences, 1(1), 95-100. In http://ekmair.ukma.edu.ua/bitstream/handle/123456789/14668/Kuzmenko_Para lelnyi_import_vazhlyvyi_mekhanizm.pdf?sequence=1\&isAllowed=y.

Kyrychenko, I. (2020). Parallel import as a portal to the parallel world. Apteka online. In https://www.apteka.ua/article/534838.

Lupkin, S. (2020). Prices for Covid-19 Vaccines are starting to come into Focus. Health News from NPR. In https://www.npr.org/sections/healthshots/2020/08/06/899869278/prices-for-covid-19-vaccines-are-starting-tocome-into-focus.

Marsh, T. (2020). Here's How to Get Discounted (Or Even Free) Flu Shots This Year. Goodrx. In https://www.goodrx.com/blog/heres-how-to-get-discounted-oreven-free-flu-shots-this-year/. 
Mazurenko, S. V. (2020). Intellectual property in the field of medicines in the context of the Agreement on Trade-Related Aspects of Intellectual Property Rights (TRIPS). Problems of legal regulation of civil relations in terms of Covid-19, 1, 50-58. In http://dspace.onua.edu.ua/handle/11300/12616.

Moskalyuk, N. B. (2013). Theoretical preconditions and practical aspects of parallel import in the system of realization of intellectual property rights to medicines. Journal of the Academy of Advocacy of Ukraine, 20(3), 1-6. In http://irbisnbuv.gov.ua/cgibin/irbis_nbuv/cgiirbis_64.exe?C21COM=2\&I21DBN=UJRN\&P21DBN=UJR N\&IMAGE_FILE_DOWNLOAD=1\&Image_file_name=PDF/Chaau_2013_3_ 16.pdf.

Musmann, T. (2020). German Government Plans Possibilities to Limit Patents In View of Corona Pandemic. Kluwer Patent Blog. In http://patentblog.kluweriplaw.com/2020/03/24/german-government-planspossibilities-to-limit-patents-in-view-of-corona-pandemic/.

Orlova, A. (2019). Patent Strategies in Pharmaceuticals: Patent Greening. Journal of the Intellectual Property Rights Court, 26, 83-89. In http://ipcmagazine.ru/patentlaw/patent-strategies-in-pharmaceuticals-patent-gardening.

PharmaTimes. (2013). Novartis loses Indian Glivec patent case. In http://www.pharmatimes.com/news/novartis_loses_indian_glivec_patent_case_ 1004741\#: :text=In\%20a\%20landmark\%20case $\% 2$ C $\% 20$ the,requirements $\% 20$ of\%20India\%27s\%20patent\%20law.

RBK Ukraine. (2020). A bill on criminal liability for overpricing of medicines to be submitted to the Rada. In https://www.rbc.ua/rus/news/radu-vnesutzakonoproekt-ugolovnoy-otvetstvennosti-1584411554.html.

Research Institute of Intellectual Property of the National Academy of Legal Sciences of Ukraine. (2020). The committee of the Verkhovna Rada of Ukraine supports the bill on the implementation of the provisions of the EU legislation in the field of IP. In http://www.ndiiv.org.ua/index.php/ua/rada-molodykhvchenykh/novyny/269-komitet-verkhovnoi-rady-ukrainy-pidtrymavzakonoproekt-shchodo-implementatsii-zakonodavstva-yes-u-sferi-iv.

Senyuta, I. Ya. (2020). Processing of personal data under the new rules: protection or violation of human rights. Higher School of Advocacy NAAU. URL: https://www.hsa.org.ua/blog/obrobka-personalnyh-danyh-v-umovah-covid-19zahyst-chy-porushennya-prav-lyudyny/.

Service, R. F. (2020). Would-be coronavirus drugs are cheap to make. Science. In https://www.sciencemag.org/news/2020/04/would-be-coronavirus-drugs-arecheap-make.

Shcherbina, Y. (2009). How to break the collusion of doctors and pharmacists? UkrRudProm. In https://www.ukrrudprom.com/digest/Kak_razrushit_sgovor_ vrachey_i_farmatsevtov.html?print.

Shirsat, M.K. (2011). Drug Patent System in India and its Application. Asian Journal of Pharmaceutical and Clinical Research, 1(1), 13-24. In 
https://www.researchgate.net/publication/313860747_Drug_Patent_System_in_ India_and_its_Application.

Shymkiv, D. (2020). The pharmaceutical industry is able to meet the needs of Ukrainians in medicines during a pandemic. UkrInform. In https://www.ukrinform.ru/rubric-economy/3014716-dmitrij-simkivpredsedatel-soveta-direktorov-darnitsa-group.html.

Silverman, E. (2020). AbbVie will allow generic copies of its HIV pill in Israel after the government approved a license. Statnews. In https://www.statnews.com/pharmalot/2020/03/20/abbvie-israel-hiv-kaletracoronavirus-covid19/.

Silverman, R. \& Lusiani, N. (2020). Oxfam America People over profits: Make Covid-19 medicines and vaccines free and fair for all. Oxfam International. In https://www.oxfam.org/en/blogs/people-over-profits-make-covid-19medicines-and-vaccines-free-and-fair-all.

Sparaciari, A. (2020). Coronavirus, a Brescia manca una valvola per i rianimatori: ingegneri e fisici la stampano in 3D in sei ore. Business insider Italia. In https://it.businessinsider.com/coronavirus-manca-la-valvola-per-uno-strumentodi-rianimazione-e-noi-la-stampiamo-in-3d-accade-nellospedale-di-chiaribrescia/.

Tomarov, I. (2020). Covid-19, respirators and patents for industrial designs. Vasyl Kisil Law Firm. In https://vkp.ua/ua/publication/covid-aparati-shtuchnogodikhannya-ta-patenti-na-promislovi-zrazki.

U.S. Government Accountability Office (GAO). (2017). Drug industry: Profits, Research and Development Spending, and Merger and Acquisition Deals. In https://www.gao.gov/products/GAO-18-40.

Ukraine. (1993). Fundamentals of Ukrainian Legislation on Health Care. In https://zakon.rada.gov.ua/laws/show/2801-12\#Text.

Ukraine. (1993). On protection of rights to inventions and utility models: Law 3687-XII. In https://zakon.rada.gov.ua/laws/show/3687-12\#Text.

Ukraine. (1993). On protection of rights to inventions and utility models: Law 3687-XII. In https://zakon.rada.gov.ua/laws/show/3687-12\#Text.

Ukraine. (1994). On protection of industrial design rights: Law. In https://zakon.rada.gov.ua/laws/show/3688-12\#Text.

Ukraine. (2018). On Amendments to Certain Legislative Acts of Ukraine Concerning the Implementation of Certain Provisions of European Union Legislation in the Field of Intellectual Property: Draft Law 9385. In http://search.ligazakon.ua/1_doc2.nsf/link1/JH78P00I.html.

Ukraine. (2020). On Amendments to Certain Laws of Ukraine Concerning the Treatment of Coronavirus Disease (Covid-19): Law 539-IX. In https://zakon.rada.gov.ua/laws/show/539-20\#Text. 
Ukraine. Cabinet of Ministers of Ukraine. (2004). On approval of the Procedure for granting permission by the to use a patented invention (utility model): Resolution. In https://zakon.rada.gov.ua/laws/show/8-2004-\%D0\%BF\#Text.

Ukraine. Cabinet of Ministers. (2020). Some issues of procurement of goods, works and services necessary for the implementation of measures aimed at preventing the occurrence and spread, localization and elimination of outbreaks, epidemics and pandemics of acute respiratory disease Covid-19 caused by coronavirus SARSCoV-2 in Ukraine: Resolution 225. In https://zakon.rada.gov.ua/laws/show/225-2020-\%D0\%BF\#Text.

Ukraine. Economic Court of Kyiv. (2018). Judgment in case $n^{\circ}$ 910/4881/18. In https://verdictum.ligazakon.net/document/78650682.

Ukraine. National Police. (2019). Police expose a group of pharmaceutical companies in bribing doctors for 140 million hryvnias. Official Site of National Police. In https://www.npu.gov.ua/news/korupcziya/policziya-vikrila-grupufarmaczevtichnix-kompanij-u-pidkupi-likariv-na-140-miljoniv-griven/\%20.

United Nations (2008). Doha Declaration on Financing for Development: Outcome of the International Conference on the Follow-up to Financing for Development to Review Progress in the Implementation of the Monterrey Consensus. In https://www.un.org/ru/documents/decl_conv/declarations/doha_findev.shtml.

United States of America \& Ukraine (1994). Treaty between Ukraine and the United States of America on the promotion and mutual protection of investments. In http://search.ligazakon.ua/l_doc2.nsf/link1/MU94065U.html.

USAID (2018). The results of the study “(Not)expensive medicine”. In https://docs.google.com/viewerng/viewer?url=http://patients.org.ua/wpcontent/uploads/2017/03/free-medicine.pdf\&hl=uk.

Wenzl, M. \& Chapman, S. (2019). Performance-based managed entry agreements for new medicines in OECD countries and EU member states. How they work and possible improvements going forward. Health Working Papers OECD, 115, 45. In https://www.oecd.org/health/health-systems/HWP-115-MEAs.pdf.

World Health Organization (2005). Remuneration guidelines for non-voluntary use of a patent on medical technologies. In https://www.who.int/hiv/amds/WHOTCM2005.1_OMS.pdf.

World Intellectual Property Organization (1883). Paris Convention for the Protection of Industrial Property. In https://www.wipo.int/treaties/en/ip/paris/.

World Trade Organization (1994). Trade-Related Aspects of Intellectual Property Rights. In https://www.wto.org/english/tratop_e/trips_e/trips_e.htm.

Zaliska, O.M. \& Stasiv, H.-O. I. (2019). "Managed access agreements” for innovative medicines to ensure the availability of drugs in European countries. Apteka. In https://www.apteka.ua/article/500494.

Zheltikhin, E. (2018). Antimonopoly Committee of Ukraine and the pharmaceutical market: pressure or protection? Legal Newspaper Online. In https://yurgazeta.com/publications/practice/antimonopolne-konkurentne-pravo/amku-tafarmrinok-tisk-chi-zahist.html. 